\title{
"Imposter-Children" in the uk Refugee Status Determination Process
}

\author{
STEPHANIE J. SILVERMAN
}

\begin{abstract}
This article describes and analyzes an emerging problematic in the asylum and immigration debate, which I cynically dub the "imposter-child" phenomenon. My preliminary exploration maps how the imposter-child relates to and potentially influences the politics and practices of refugee status determination in the United Kingdom. I argue that the "imposter-child" is being discursively constructed in order to justify popular and official suspicion of spontaneously arriving child asylum-seekers in favour of resettling refugees from camps abroad. I also draw connections between the discursive creation of "imposter-children" and the diminishment of welfare safeguarding for young people. Further complicating this situation is a variety of sociocultural factors in both Afghanistan and the United Kingdom, including the adversarial UK refugee status determination process, uncertainty around how the United Kingdom can "prove" an age, and a form of "triple discrimination" experienced by Afghan male youth. Through unearthing why the "imposter-child" is problematic, I also query why it is normatively accepted that non-citizens no longer deserve protection from the harshest enforcement once they "age out" of minor status.
\end{abstract}

\section{Résumé}

Cet article décrit et analyse une problématique émergente dans le débat sur l'asile et l'immigration, que je dénomme d'une façon cynique le phénomène des "enfants-imposteurs». Mes explorations préliminaires démarquent comment "l'enfant-imposteur» est relié aux politiques et pratiques de détermination du statut de réfugié au Royaume-Uni, et comment il les influence potentiellement.
Je soutiens que l'enfant-imposteur est constitué comme discours afin de justifier la méfiance populiste ainsi qu'offcielle à l'égard des chercheurs d'asiles qui sont issus des arrivées spontanées, pour favoriser plutôt la réinstallation de réfugiés arrivant de camps à l'étranger. Je trace également des liens entre la création discursive de ces "enfantsimposteurs» et la réduction des aides sociales publiques pour les jeunes personnes. Cette situation est rendue encore plus compliquée par divers facteurs socioculturels en Afghanistan ainsi qu'au Royaume-Uni, dont notamment le processus antagoniste de détermination du statut de réfugié au Royaume-Uni (DSR), l'incertitude autour de la "preuve» d'âge dans le pays, et une forme de "triple discrimination" subie par les jeunes Afghans de sexe masculin. En faisant ressortir les raisons pour lesquelles l'enfant-imposteur est problématique, j'interroge également pourquoi il est normativement acceptable que les non-citoyens ne méritent plus d'être protégés des activités coercitives et d'exécution de règlements les plus sévères une fois qu'ils ont dépassé "l'âge limite» de statut de mineur.

\section{Introduction $^{1}$}

I $\mathrm{n}$ the United Kingdom, refugee status determination (RSD) is a declaratory process performed usually in an administrative tribunal to adjudicate whether spontaneously arriving asylum-seekers should be granted asylum and its accompanying protection against removal. ${ }^{2}$ RSD is founded on a definition of the refugee elaborated in the 1951 Convention relating to the Status of Refugees and its 1967 Protocol (the Refugee Convention). Along with some other vulnerable groups identified during screening, unaccompanied or separated asylum-seeking children ${ }^{3}$ are 
granted access to preferential treatment over adults while navigating the UK RSD process. This access includes entitlements to housing and legal aid, and a staying of detention and deportation orders until the claimant "ages out" of the protective shield of child status.

The special protections for children in the RSD process are increasingly valuable and sought out in a world of 65.3 million forcibly displaced people, of whom 11 million are child refugees and asylum-seekers searching for safety. In $2015,88,245$ unaccompanied or separate children applied for asylum in the EU, including 3,045 in the United Kingdom, representing an increase of 56 per cent from the previous year. ${ }^{4}$ Recent European Commission data indicate nearly 3,500 asylum applications from unaccompanied or separate children in January 2016 alone. 5 The majority of these children hail from Afghanistan, the Syrian Arab Republic, and Somalia. ${ }^{6}$ UNICEF documents the journeys of the thousands of children risking their lives weekly to reach the United Kingdom. 7

With more than 4,00o unaccompanied or separated asylum-seekers under the age of eighteen coming into local authority care in the United Kingdom, ${ }^{8}$ the government is being stretched to meet its welfare needs. Notably, these numbers do not include the equally high number of de facto child refugees who are on UK soil but not registered in the RSD process, as well as the more than 10,000 unaccompanied or separated migrant children in the EU who are "now missing, and are potentially victims of sexual exploitation, trafficking or other criminal activity."

Beginning in the decade preceding the European migrant crisis, scholars became increasingly interested not only in how but also why liberal states afford protections to child asylum-seekers over and above those of adults in the UK RSD process. Researchers are exploring when and how the idea of children as "moral touchstones" in UK society intersects, dominates, or subverts citizenship, irregularity, asylum, and other statuses in terms of social worlds, legal rights, and policy arrangements at a variety of local, regional, national, and international levels. ${ }^{10}$ Children's rights and protections have risen to the top of many political and social agendas and have been made symbolically and legally meaningful since at least the 1990 s with the promulgation of the United Nations Convention on the Rights of the Child (UNCRC). ${ }^{11}$ Yet research demonstrates how immigration enforcement priorities can override these rights and protections, leading to "perverse outcomes" that would be otherwise unacceptable for children. ${ }^{12}$

These outcomes also result partially from deeply ingrained notions of "race," class, and other markers converging with the administrative nature of the RSD process. Despite the fact that women and children are now thought to comprise the majority of the forcibly displaced worldwide, the Refugee Convention's binary understanding interprets and privileges "adult male" standards above gender-, sexuality-, and age-based persecution to the exclusion of most other protection claims. ${ }^{13}$ Likewise, the RSD process can be blighted by underlying presumptions about the deservingness of some groups in contradistinction to the exploitative tendencies of others. Researchers describe pervasive assumptions about the "bogus refugee" with "socio-economic motivations" who presents a "problem" of genuineness for the RSD process $^{14}$ and a "threat" to the British people writ large. ${ }^{15}$ As will be explained below, unaccompanied or separated asylum-seeking children who spontaneously arrive present an admixture of deservingness and threat, compounded by their independent migrations to the United Kingdom.

Against such a complex background, this article unearths and analyzes a new "threat" to the UK RSD system: termed here as "imposter-children," they are asylum-seekers who claim to be unaccompanied or separated asylum-seeking children specifically to receive preferential treatment in the RSD process. I coin the term “imposter-children” cynically. My intention is to reflect the state's antagonism or, at the very least, non-data-supported suspicion that some foreign nationals are manipulating the RSD process by consciously pretending to be something they are not (children). I am also using "imposter-children" to unearth the government's conclusion that these actions should be detected and either reversed or punished as a matter of safeguarding the RSDprocess (and potentially the British people).

In addition to sketching and describing "imposterchildren," I am also arguing that this imagined community of adults posing as unaccompanied or separated children challenge the RSD process in important ways. The proffered "solution" is the process of age-disputing imposter-children and then conducting age assessments. Long controversial, these assessments continue to play a key role in legitimating "real" children. By cordoning off unaccompanied or separated children and releasing them from the threats of detainability and deportability, but also rooting out the nefarious adults who seek to undermine this system, my argument is that the state is working to make its unjust and unfair RSD process appear more defensible in the face of an escalating global crisis of displaced children.

\section{Children Negotiating the UK Refugee Status Determination Process}

As the most commonly invoked and interpreted area of international law, refugee status determination (RSD) is a manifestation of particularizing global ideas into nationallevel bureaucratic decision-making. ${ }^{16}$ The UK RSD process is notable for featuring a formally adversarial structure, onus 
placement of proving Refugee Convention persecution on the asylum-seeker, and no automatic access to legal counsel or translation. Judgments vary across regions and venues. ${ }^{17}$ Findings of credibility are pivotal for securing Refugee Convention status and the right to stay. ${ }^{18}$ In this hostile setting, young people are "expected to give consistent and coherent accounts of their past, whilst often having no independent adult to support them and sometimes without a legal representative. Many are even forced to repeat the process at the age of seventeen and a half, damaging the new lives they have managed to build in a foreign country." 19

While awaiting an RSD outcome, children ${ }^{20}$ are granted fuller access to welfare benefits, health care, and educational opportunities than adults. The local authority-usually a district, city, or county council-provides basic accommodation and educational needs, and assumes increased duties towards those aged sixteen years old and younger, than those aged eighteen years. While being of minor age does not confer automatic rights to refuge and permanent settlement, it is more difficult to remove a child refused asylumseeker than an adult, not least because many receiving states do not have the facilities to care for them. ${ }^{21}$

International law, including the UNCRC, and an array of national UK legislation are designed to protect children, including unaccompanied or separated asylum-seeking children. UNCRC Article 3 elucidates the principle that "in all actions concerning children ... the best interests of the child shall be a primary consideration" and requests complementary protection. Section 55 of the Borders, Citizenship and Immigration Act 2009 acknowledges a duty on the home secretary to make arrangements ensuring that immigration and asylum functions (among others) are discharged having regard to the need to safeguard and promote the welfare of all children. This duty is similar to the public duty of care placed on other agencies by the Children Acts 1989 and 2004: local authorities are required to protect and promote children's welfare, and the courts are expected to take children's welfare as the principal consideration in their decisions.

In 2007, Crawley documented the deleterious effects of the RSD process for age-disputed children. She argued that a "culture of disbelief" permeates the UK RSD process and that the legal, welfare, and mental health consequences for children attempting to navigate this system are serious. Crawley emphasized that, even when successfully obtained, the government-provided welfare and support level to children is limited. ${ }^{22}$

Crawley also highlighted the fears of unaccompanied or separated asylum-seeking children of reaching 17.5 or 18 years of age. These youth "age out" of the protections from detention and removal reserved for children. In the United Kingdom, the majority of age-confirmed unaccompanied or separated children can be granted Discretionary Leave to Remain for three years, or until reaching 17.5 years old, whichever is the shorter period. If their applications to extend their Discretionary Leaves to Remain fail (as "the overwhelming majority" do), they are reclassified as socalled Appeal Rights Exhausted Care Leavers. ${ }^{23}$ Without a further legal basis to stay in the United Kingdom and deemed appeal rights exhausted, such young people will become "unlawfully in the UK." ${ }^{24}$

Aged-out youth lose their Leaves to Remain simultaneous to the unravelling of their access to the relatively rich social fabric of accommodation and support provided by the local authority. UK immigration law prohibits the local authority from providing money, support, or housing to unaccompanied or separated youth 17.5 years of age or older. Aging-out or aged-out youth have to move out of their foster families, ${ }^{25}$ and many become detainable, removable, and at risk of destitution. ${ }^{26}$ Anxieties about return haunt many young people's stays in the United Kingdom, ${ }^{27}$ and questions remain about whether these youth are being protected or simply held in limbo for a number of years until their claims can be assessed.

Macklin ${ }^{28}$ persuasively argues that most liberal states "deplore" spontaneously arriving asylum-seekers: the "spontaneous flow of non-citizens possessing a limited legal claim to entry represents a threat to sovereignty-asborder-control, even though it is an exception to which states voluntarily bind themselves by signing the Refugee Convention." Accordingly, liberal states position "deserving refugees" as "always already 'over there"”-with "over there" referring increasingly to camps populated by Refugee Convention-certified persons-and "like magic, the refugee is disappeared from North America, from Western Europe, and from Australia, displaced by the pariah illegal." 29

As an independently migrating agent, the spontaneously arriving child asylum-seeker embodies the problematic ellipsis of deservingness being equated with "over there" but also presents an additional series of moral and practical conflicts for liberal states. As evidenced by the consternation around realizing the Section 55 duty, children trigger state-based duties of migration enforcement qua foreign nationals making demands on the state, but also of welfare safeguarding qua "socially constructed attributes of vulnerability, passivity and lack of agency."30 Their journeys are not appreciated as valiant efforts to escape camp-life ${ }^{31}$ but rather subversions of the international burden-sharing system. In response, the state is being asked to discharge its duties as migration "gatekeeper" but also as parens patriae, or the chief welfare agent tasked with acting as a parent or guardian to all children..$^{2}$ Language tropes signal these Janus-faced roles: "Where a child is 'looked after' by 
the Local Authority the Local Authority acts as the child's 'corporate parent' ... under the Children (Leaving Care) Act 2000 the Local Authority will also owe a 'looked after' child longer-term duties as they progress into adulthood." 33 In a period of punitive migration controls and restricted welfare spending, this contestation between roles, duties, and responsibilities will be heightened.

This dilemma adheres to advocates for non-citizen children as well. They tend to position unaccompanied or separated child asylum-seekers as inherently vulnerable actors who deserve the community's compassion and freedom from detention and removal. Following Zetter,34 this "bureaucratic identity" not only describes how advocates genuinely feel but also constructs them "in convenient images" to achieve certain policy goals. A danger is that a small, socially constructed, age-based minority population is being cordoned off as deserving of freedom from detention and deportation, to the exclusion of the rest. ${ }^{35}$ By campaigning that children deserve special protections in the RSD process, they inadvertently legitimize an adjudication system that is unfair and unjust to everyone else. ${ }^{36}$

\section{Assessments for Age-Disputed Asylum-seekers}

As mentioned, "age disputing" names the process for determining the biological ages of people whose minor statuses are disbelieved and who are usually without satisfactory identification documents; it is rare for European immigration officials to dispute the ages of persons claiming to be adults but whom they suspect of being children unless in cases of human trafficking or involvement in commercial sex work..$^{37}$ Although they invariably produce a range of two to three years, age assessments are meant to settle age disputes.

In the United Kingdom, most age disputes occur at the screening stage, when UK social workers and immigration officials are working to establish the identities of asylum claimants as well as their route into the country. The choice to dispute age is a discretionary decision undertaken by individual officials based on their subjective judgments. In the year ending September 2015, 590 asylum applicants in the United Kingdom had their ages officially disputed; 574 underwent age assessments, of whom 65 per cent were diagnosed as having a birthdate suggesting they were over eighteen years old within the one- to two-year age range. ${ }^{38} \mathrm{uK}$ process guidance of age instructs immigration officials to afford the benefit of the doubt to asylum-seekers whose age has not been accepted, "unless their physical appearance/ demeanour very strongly suggests they are significantly over 18 "; 39 subsequent inquiries have found that the institutional culture of disbelief impedes the benefit of the doubt, however, and that this situation is "of concern." 40
European age assessments typically adhere to a psychosocial model whereby social workers cooperate with immigration officials to conduct "interviews with and observations of the young people (with contributions by any other professionals working with them), exploring their lives (physical, emotional, familial, educational and beyond) particularly in relation to their social environment, both current and past." ${ }^{11}$ If the psychosocial exam is inconclusive, technologybased age assessments may be undertaken. Busler reports that " 24 out of 30 [European] countries ... use carpal (hand/ wrist) X-rays, with approximately half using collar bone and/or dental X-rays as part of their age assessment process." 42 There are two technologies that may be employed in the United Kingdom: (1) bone age and dental maturity assessment through X-rays and magnetic resonance imaging and ultrasound; and (2) anthropometric measurements without X-rays, including physical size (height and weight growth) and sexual development (e.g., pubic hair or breast development).

There is no statutory procedure for conducting age assessments in the United Kingdom. Justice Sir Stanley Burnton provides broad guidance in the 2003 case, $R$ (on the application of B) $v$ London Borough of Merton, [2003], or Merton, and most practice is based on subsequent case law. According to Merton guidelines, the local authority has a responsibility to "elicit the general background of the applicant, including his family circumstances and history, his educational background, and his activities during the previous few years" (para. 37). An interpreter may be used to minimize misunderstanding. Any doubt about the credibility of the young person's information needs to be substantiated and tested (para. 37). ${ }^{43}$

Merton encourages holistic assessments while being wedded to precise definitions of age, vulnerability, and maturity predicated on biology. Although it emphasizes credibility, Merton legally enshrines the holistic practices of "interaction, social history, family circumstances, education, self-care, and health" when conducting age assessments. ${ }^{44}$ Merton also holds that once a case reaches court, it is necessary to determine the precise age of the claimant, not merely that the claimant is currently a child. ${ }^{45} \mathrm{~A}$ recent small-scale study found that most young people refused asylum on credibility grounds had also been subject to age disputes. ${ }^{46}$ If the holistic determination under Merton is unsuccessful, the Home Office may use invasive technologies to determine chronological or biological age, although, as mentioned, a precise level of accuracy on age is virtually impossible to achieve with these technologies, and significant harms may accrue (see "Discussion" section).

Importantly, as mentioned, the likelihood of gaining an accurate age assessment decreases with age, 47 thus 
frustrating the Merton aims of determining a precise age. This disconnect is especially important when considering that it is the population of borderline aged-out youth who are subject to the majority of age disputes and for whom the arbitration over one biological year is literally life-changing.

\section{Triple Discrimination against Male Afghan "Imposter-Children"}

Documented identity is thus key to access child-only protections and forgoing age assessments. Birth registrations, for example, are thought to establish identities, provide a link to a particular state, facilitate access to social security and other services, impede risks such as trafficking and illegal adoption, and increase the likelihood of family reunification..$^{4}$ Flagging the significance of these documents for RSD processes, UNCRC Article 7 imposes a requirement upon all signatory states to register children immediately after birth.

For many displaced people, however, such vital documents are not easy to obtain, keep, or present. Estimates hold, for example, that about 51 million children born in 2006 have not had their births registered. ${ }^{49}$ Substandard bureaucratic infrastructure during times of instability affect displaced people's abilities to document their biological ages..$^{50}$ During wartime, documents may be destroyed intentionally or accidentally, and children may also flee without bringing along their identification documents. Smugglers and traffickers also take away documents during journeys. "Imposter-children" may be falsely accused of destroying their birth registrations or other identity documents when, in truth, they were never provided with any. The scholarly and policy debates over important questions such as whether a biological age coheres with social age, how a person's maturation ought to be documented, the ethics of states harnessing mobilities through monopolizing documentation, and why migrants without identities are interpolated as threats to citizens remain unsettled; however, "bureaucratic identity" à la Zetter continues to dominate RSD processes, and certain documents form its beating heart.

The problem of documenting biological age is particularly acute for Afghans. The Afghan government did not have bureaucratic or institutional capacity to register births during the protracted wars of the 1980s and 1990s. Since identification cards and driving licences were not commonly used anyway, and because government paperwork requested Islamic calendar dates, families often forewent recording their babies' exact birthdates..$^{51}$ In 2003, coverage of live birth registration was at 6 per cent, making the burden of proof of age determination much more onerous for Afghan nationals than for those from European countries..$^{2}$

Against this background, the United Kingdom is removing an increasing number of aged-out refused asylum-seekers, of whom a target population appears to be spontaneously arriving Afghans: Gladwell and Elwynn ${ }^{53}$ report that 20 aged-out Afghan nationals were forcibly removed from the United Kingdom in 2009, but that this figure increased more than three-fold to 70 in 2010 , increasing again to 100 in 2011. In 2016, the minister for immigration admitted that over the past nine years, 2,748 aged-out young people had been removed to Iraq, Iran, Libya, Syria, and other countries, with the majority $(2,018)$ removed to Afghanistan.

In August 2015, a judge issued a blanket ban on removals to Afghanistan because the country was too dangerous; but in the following March 2016, the Court of Appeal overturned the injunction, clearing the way for the Home Office to resume chartered flights for aged-out unaccompanied minors. 54 Common difficulties for aged-out Afghans being involuntarily return to Kabul from the United Kingdom include reconnecting with family and social networks; the psychosocial impact of insecurity and poverty in Afghanistan; lack of education and employment opportunities: actual and perceived "Westernization" of returnees; and risky attempts at re-migration to Europe.55 The removals occurred in the midst of deteriorating security conditions in Kabul - the site of handover to Afghan authorities - and despite warnings about the dangers of repatriations by a prominent Afghan minister. ${ }^{56}$

Following Macklin, there seems to be cultural disconnect between the levels of tolerance and support being extended to unaccompanied or separated children resettled from camps, versus those who arrive spontaneously to claim asylum through the RSD process. In sum, the former are more likely to be labelled victims, while the latter are threats. In relation to the particular threat posed by aged-out Afghan males, there may also be a gendered and racialized dimension to the characterization: following Rygiel's conceptualization of "hegemonic masculinity," 57 these youth are simultaneously innocent victims of the wars in Afghanistan but also illegal and criminal migrants. Their nationality makes both the Afghan children and the Afghan aged-out youth seem less deserving of permanent protection through indefinite leave to remain in the United Kingdom..$^{8}$ In a pan-European situation of allegedly scarce resources where asylum is meted out only to a fortunate minority, and where Refugee Convention-certified children from camps are prioritized above spontaneous arrivals, it is likely that Afghan male youths will continue to be age-disputed, and perhaps this treatment will normalize them into becoming ultimate "imposter-children."

\section{Discussion}

The antipathy towards spontaneously arriving asylumseekers claiming to be children animates a February 2016 
interview that British Member of Parliament for Monmouth David Davies gave to the Daily Mail newspaper. In it, the MP spoke of the "complete ruse" of adults posing as children: 'These people come over here and get preferential treatment by claiming they're 12 and no one wants to call them out. We've seen how bad things can get with other incidents in Europe ... It's becoming common place." 59 The incident that sparked the heated interview was tragic: an Afghan unaccompanied or separated asylum-seeking child allegedly attacked his Welsh foster family. A subsequent age assessment of dental maturity indicated that the Afghan had a chronological or biological age of at least twenty years old, not the age of sixteen years he claimed upon arrival. ${ }^{60}$ In October 2016, the minister of state indicated that a twentyeight-day age verification process may be used for resettled children from the now-razed Calais migrant settlementmany of whom are Afghan nationals-but he ruled out intrusive dental and X-ray checks for this group. ${ }^{61}$

My focus in this article has been unearthing and analyzing why MP Davies and others are morally offended when adult asylum-seekers pose as children. I shorthand this logic to the "imposter-children" phenomenon. Surely part of the Welsh tragedy is that the host family was "tricked" into hosting an adult. In a climate of accelerated and punitive border, immigration, and asylum enforcement, childonly protections are increasingly valuable, to the asylum seeker but also to the moral sense of deservingness felt by the community offering them. Many community members feel that it is wrong for foreign nationals over eighteen years of age to access these protections, and, further, that such unwarranted access is a concerted act of deceit, subterfuge, or criminality. These biological adults are "buying time" in the United Kingdom that they do not deserve, and should be rooted out, exposed, and potentially removed.

Far from extending the benefit of the doubt, and despite repeated injunctions from civil society, the government seems at times overly eager to identify adults in the RSD process whose claims to be children can be "unproven" with age assessments. This eagerness comes at real costs. While they are denounced when they take too long to complete or necessitate too much scrutiny or contact in a non-culturally sensitive manner, age assessments should also be criticized when conducted too hastily or with too much distance. The consequences of either mistake can be exposure to enforcement actions supposedly reserved for adults. Significantly, spontaneously arriving children are consistently co-mingled with adults in UK detention centres and prisons, ${ }^{62}$ despite government promises to the contrary. Yet there is also often a feeling of moral outrage when it is revealed that children are co-mingled with adults in detention. ${ }^{63}$ However, when the state broadcasts that some adult foreign nationals are manipulating the RSD process by consciously pretending to be something they are not (child asylum-seekers), the implication is that aspersion should be cast not only on the fraudulent minor status but also on the asylum-seeker's claim to stay.

Indeed, the trend is real enough that a cottage industry of private, for-profit social workers has coalesced to offer independently contracted and "unbiased" age assessments for a price. ${ }^{64}$ The rubrics and rhetoric of age assessments play a key role in discursively legitimating the difference between imposters and "real" children. For example, the term Merton compliant has emerged to describe a local authority assessment that has been conducted in accordance with case law. By cordoning off children for special treatment, but also rooting out the nefarious adults who would otherwise undermine this system, the state is able to make its unjust and unfair RSD process appear more defensible.

A final note should be offered on the ethical propriety of invasive age assessments in UK society. Though only used sporadically, they are still in play and their results are respected, such as the dental maturity exam conduced on the Afghan fostered in Wales. The normative acceptance that immigration officials may resort to these technologies at all is worrying. The technologies are invasive and contentious, and they may psychologically harm children. ${ }^{65}$ They have an unacceptably high margin of error. ${ }^{66}$ There is no standardized approach between or within European states. ${ }^{67} \mathrm{~A}$ precise level of accuracy is virtually impossible to achieve with these technologies, ${ }^{68}$ and the likelihood of gaining an accurate age assessment decreases with age. ${ }^{69}$ Thus, in addition to the harms incurred, the fact that "experts agree that age assessment is not a determination of chronological age but an educated guess" 70 calls into question the baseline utility of assessing a population almost always verging on minor status by a couple of years.

European governments have been reluctant to acknowledge the damage that age assessments can cause. One reason for the reluctance could be that it would provoke recognition of a paradox: invasive age assessments require informed consent. The Oxford English Dictionary defines informed consent as "permission granted in full knowledge of the possible consequences, typically that which is given by a patient to a doctor for treatment with knowledge of the possible risks and benefits." Since informed consent can be given only by adults, children submitting to invasive age assessments are being forced to do something they cannot legally do: in order to prove their minor status and gain basic rights such as release from detention, protection from removal, and access to welfare support, they must submit to a procedure from which children are legally prevented to consenting. While migration studies has been attuned to 
issues of informed consent in research methodologies and ethics, ${ }^{71}$ the problematic presentation of "imposter-children" presents a novel opportunity to explore further the role of informed consent as it relates and informs not only to the researcher-refugee relationship but also to the immigration official-refugee dynamic.

\section{Notes}

1 I wish to extend my thanks to Christina Clark-Kazak for encouraging and shepherding this line of thinking. I would also like to acknowledge the very helpful feedback from Idil Atak and other participants at the August 2015 "Age Discrimination in Migration Policy" workshop at Glendon College; the detailed and constructive reviews by the two anonymous journal referees; the thoughtful comments and discussions on earlier versions with Esra S. Kaytaz, Evelyne Massa, Petra Molnar, and Amy Nethery; and much-needed support from Alice Lowinsky at a critical time.

2 The three primary categories of state-enforced or enforceable departures in the United Kingdom are (1) deportations, (2) administrative removals, and (3) voluntary departures. The Migration Observatory explains (1) deportation may be the most common in casual parlance, but it is actually "a specific term that applies to people and their children whose removal from the country is deemed "conducive to the public good" by the Secretary of State"; (2) removals is a much larger category referring to "the enforced removal of non-citizens who have either entered the country illegally or deceptively, stayed in the country longer than their visa permitted, or otherwise violated the conditions of their leave to remain in the UK"; and, finally, (3) referring to the method of departure, not the choice to leave, voluntary departures include people who depart by official Assisted Voluntary Return programs, others "who make their own travel arrangements and tell the authorities, or approach them for help with the arrangements," and those people who simply depart without telling the Government. Migration Observatory, "Deportations, Removals and Voluntary Departures from the UK," 19 August 2016, http://www.migrationobservatory.ox.ac.uk/resources/ briefings/deportations-removals-and-voluntarydepartures-from-the-uk/). Aged-out Afghan youth often qualify for Assisted Voluntary Return programs.

3 The uk Home Office defines unaccompanied or separated asylum-seeking children as persons under eighteen years of age when their asylum application is submitted; who are applying for asylum in their own right; and are separated from both parents and not being cared for by an adult who in law or by custom has responsibility to do so.

4 House of Lords, European Union Committee, "Children in Crisis: Unaccompanied Migrant Children in the EU," in 2nd Report of Session 2016-17, House of Lords, 2016, chap. 3.
5 Monique El-Faizy, "Unaccompanied Minors at Most Risk as Refugees Amass at EU Borders," France 24, 3 September 2016, http://www.france24.com/en/20160309-minorsmost-risk-migrants-eu-borders-children-syria-europeanunion.

6 Emily Garin, Jan Beise, Lucia Hug, and Danzhen You, Uprooted: The Growing Crisis for Refugee and Migrant Children (New York: United Nations Children's Fund, 2016), 38-9.

7 UNICEF UK, "Children Risking Their Lives over 2,000 Times a Week to Reach the UK," news release, 5 September 2016, http://www.unicef.org.uk/Media-centre/Pressreleases/Children-risking-their-lives-over-200o-times-aweek-to-reach-the-uk/.

8 Charlotte England, "British Authorities Visit Calais Refugee Camp to Discuss Care of Unaccompanied Refugee Children," Independent, 17 August 2016, http://www.independent.co.uk/news/uk/home-news/calais-jungle-refugeecamp-uk-councillors-visit-refugee-migrant-childrencare-a7195176.html.

9 House of Lords, "Children in Crisis," 8.

10 See, e.g., Viviene E. Cree, Gary Clapton, and Mark Smith, "The Presentation of Child Trafficking in the uk: An Old and New Moral Panic?," British Journal of Social Work 44 (2014): 418-33; Clotilde Giner, "The Politics of Childhood and Asylum in the UK," Children \& Society 21 (2007): 2496o; Rachel Hek, Nathan Hughes, and Roberto Ozman, "Safeguarding the Needs of Children and Young People Seeking Asylum in the UK: Addressing Past Failings and Meeting Future Challenges," Child Abuse Review 21 (2012): 335-48; Nando Sigona and Vanessa Hughes, No Way Out, No Way In: Irregular Migrant Children and Families in the UK, COMPAS, 2012, https://www.compas.ox.ac.uk/media/ PR-2012-Undocumented_Migrant_Children.pdf.

11 Bridget Anderson, "Where's the Harm in That? Immigration Enforcement, Trafficking, and the Protection of Migrants' Rights," American Behavioral Scientist 56 (2012): 1249.

12 Cree, Clapton, and Smith, "Presentation of Child Trafficking," 432.

13 Heaven Crawley, Ending the Detention of Children: Developing an Alternative Approach to Family Returns (London: Centre for Migration Policy Research, 2010); Alice A. Edwards, "Age and Gender Dimensions in International Refugee Law," in Refugee Protection in International Law: UNHCR's Global Consultations on International Protection, ed. Erika Feller, Volker Turk, and Frances Nicholson, 46-8o (Cambridge: Cambridge University Press, 2014), 47; Rebecca Hamlin, Let Me Be a Refugee: Administrative Justice and the Politics of Asylum in the United States, Canada, and Australia (Oxford: Oxford University Press, 2014).

14 E.g., Liza Schuster, "Turning Refugees into 'Illegal Migrants': Afghan Asylum-seekers in Europe," Ethnic and Racial Studies 34 (2011): 1392-1407; Susan E. Zimmerman, "Reconsidering the Problem of 'Bogus' Refugees 
with 'Socio-economic Motivations' for Seeking Asylum," Mobilities 6 (2011): 335-52.

15 Margaret S. Malloch and Elizabeth Stanley, “The Detention of Asylum-seekers in the UK: Representing Risk, Managing the Dangerous," Punishment \& Society 7 (2005): 55.

16 Hamlin, Let Me Be a Refugee, 7.

17 BID (Bail for Immigration Detainees), A Nice Judge on a Good Day: Immigration Bail and the Right to Liberty (London: BID); Bill MacKeith and Bridget Walker, "Immigration Bail Hearings: A Travesty of Justice? Observations from the Public Gallery," 2011, http://closecampsfield.files .wordpress.com/2011/o3/ccc-bop-report-low-res.pdf; Caroline White, “'Get Me out of Here': Bail Hearings of People Indefinitely Detained for Immigration Purposes." Anthropology Today 28, no. 3 (June 2012): 3-6.

18 Robert Thomas, "Assessing the Credibility of Asylum Claims: EU and UK Approaches Examined," European Journal of Migration and Law 8 (2006): 79.

19 Refugee and Migrant Justice, Does Every Child Matter? Children Seeking Asylum in Britain (London: Refugee and Migrant Justice Publications, 2009), 23.

20 In England and Wales and in Northern Ireland a minor is a person under the age of eighteen; in Scotland, under the age of sixteen.

21 See below; also, on Afghanistan, see Esra S. Kaytaz, “The Resigned, the Restless, and the Resilient: Risk Perceptions among Afghan Migrants in Turkey" (DPhil thesis, University of Oxford, 2015), 182.

22 Heaven Crawley, "When Is a Child Not a Child? Asylum, Age Disputes and the Process of Age Assessment," ILPA Research Reports (London: Immigration Law Practitioners' Association, 2007), esp. chap. 7; see also Crawley, "No one gives you a chance to say what you are thinking': Finding Space for Children's Agency in the UK Asylum System," Area 42 (2010): 162-9.

23 Catherine Gladwell, "No Longer a Child: From the uk to Afghanistan," Forced Migration Review 44 (2013): 62.

24 Catherine Gladwell, Emily Bowerman, Bryony Norman, Sarah Dickson, and Abdul Ghafoor, After Return: Documenting the Experiences of Young People Forcibly Removed to Afghanistan (London: Refugee Support Network Reports, 2016), 56.

25 Ibid., 10.

26 Kim Robinson and Lucy Williams, "Leaving Care: Unaccompanied Asylum-Seeking Youth Afghans Facing Return," Refuge: Canada's Journal on Refugees 31 (2015): 85.

27 Crawley, "When Is a Child Not a Child?"; Office of the Children's Commissioner, "What's going to happen tomorrow?' Unaccompanied Children Refused Asylum," Reports of the Children's Commissioner, April 2014, 4; Robinson and Williams, "Leaving Care"; Jim Wade, "Preparation and Transition Planning for Unaccompanied Asylum-Seeking and Refugee Young People: A Review of Evidence in England," Children and Youth Services 33 (2011): 2424-30; Gladwell et al., After Return.
28 Audrey Macklin, "Disappearing Refugees: Reflections on the Canada-U.S. Safe Third Country Agreement," Columbia Human Rights Law Review 36 (2005): 367.

29 Ibid., 369.

30 Sarah Judith Cemlyn and Miriam Nye, "Asylum-seeker Young People: Social Work Value Conflicts in Negotiating Age Assessment in the UK," International Social Work 55 (2012): 682 .

31 Despite coming under the Officer of the United Nations High Commissioner for Refugees (UNHCR) protection mandate, camp life can be onerous and even harmful to Refugee Convention-certified children. Children and young people comprise an estimated 40 per cent of the 10,000 people at the Idomeni camp on Greece's border with Macedonia, a place that the UNHCR's spokesperson for Central Europe described as "not fit for human beings." Kathleen Schuster, "UNHCR Spokesman: EU Must Do More for Refugee Children," Deutsche Welle, 7 September 2016, http://www.dw.com/en/unhcr-spokesman-eu-mustdo-more-for-refugee-children/a-19532577. More than half- 3.7 million-of the approximately 6 million schoolage persons under its mandate have no school to attend. UNHCR: The un Refugee Agency, "Missing Out: Refugee Education in Crisis." September 2016, http://www.unhcr .org/57d9do1do.

32 Jacqueline Bhabha, "Internationalist Gatekeepers?: The Tension between Asylum Advocacy and Human Rights," Harvard Human Rights Journal 15 (2002): 155-82.

33 Gladwell et al., After Return, 57.

34 Roger Zetter, "More Labels, Fewer Refugees: Remaking the Refugee Label in an Era of Globalization," Journal of Refugee Studies 20 (2007): 173.

35 In national contexts of increasing reliance on deportation, Castañeda and Corrunker document how certain populations in Germany and in the United States are deemed worthy of staying in the countries, respectively. According to the authors, German informal criteria for "deserving" deportation protection include health, pregnancy, and non-refoulement; in the United States, integration and fondness for the adopted country are key, and this reasoning speaks to the presidential protection against removal being granted to the DREAMers movement of undocumented youth who are publicly acknowledging their irregular status but also their contributions to the U.S. political and social community. Heide Castañeda, "Deportation Deferred: 'Illegality,' Visibility, and Recognition in Contemporary Germany," in The Deportation Regime: Sovereignty, Space, and the Freedom of Movement, ed. Nicholas P. DeGenova and Nathalie Peutz, 245-61 (London: Duke University Press, 2010); Lori Corrunker, "Coming out of the Shadows: DREAm Act Activism in the Context of Global Anti-Deportation Activism," Indiana Journal of Global Legal Studies 19 (2012): 143-68.

36 Bhabha, "Internationalist Gatekeepers?," 161; Alison Mountz, Kate Coddington, R. Tina Catania, and Jenna 
Loyd, "Conceptualizing Detention: Mobility, Containment, Bordering, and Exclusion," Progress in Human Geography 37 (2013): 527; Kim Rygiel, "Bordering Solidarities: Migrant Activism and the Politics of Movement and Camps at Calais," Citizenship Studies 15 (2011): 1-19.

37 Separated Children in Europe Network, "Position Paper on Age Assessment in the Context of Separated Children in Europe," International Save the Children Alliance and the United Nations High Commissioner for Refugees, 2012, 7, http://www.scepnetwork.org/images/16/163.pdf.

38 uk Home Office, "National Statistics: Asylum," 26 November 2015, https://www.gov.uk/government/publications/ immigration-statistics-july-to-september-2015/asylum.

39 uk Home Office, "Assessing Age: Guidance," last modified 17 June 2011, 2.2.1, https://www.gov.uk/government/ uploads/system/uploads/attachment_data/file/257462/ assessing-age.pdf; emphasis in original.

40 Joint Committee on Human Rights, Human Rights of Unaccompanied Migrant Children and Young People (London: House of Lords and House of Commons, 2014).

41 Debbie Busler, "Psychosocial Age Assessments in the UK," Forced Migration Review 52 (2016) 87.

42 Ibid.

43 See, e.g., Hek, Hughes, and Ozman, "Safeguarding the Needs of Children," 340.

44 Cemlyn and Nye, "Asylum-seeker Young People," 681.

45 Two recent Court of Appeal cases have determined that Merton compliance is to be determined as at the date of the assessment, and not as against any later case law, and that a judicial finding of the First-tier Tribunal (FTT) of a claimant's age may in itself constitute "clear and credible documentary evidence" that he or she is eighteen or over. On vs [2015] EWCA Civ 1142 and zS (Afghanistan) [2015] EWCA Civ 1137, see Matt Donmall, "Court of Appeal: Immigration Age Assessments and Merton," uk Human Rights Blog, 6 January 2016, http://ukhumanrightsblog. com/2016/o1/o6/court-of-appeal-immigration-age-assessments-and-merton/.

46 Richard Warren and Sheona York, "How Children Become 'Failed Asylum-Seekers,'” Kent Law Clinic, 2014, https:// www.kent.ac.uk/law/clinic/how_children_become_ failed_asylum-seekers.pdf.

47 Tim Cole, "People Smugglers, Statistics and Bone Age," Significance 9 (2012): 8-12.

48 Office of the United Nations High Commissioner for Refugees, Birth Registration, Office of the United Nations High Commissioner for Refugees Child Protection Issue Brief, 2013, 3.

49 Al Aynsley-Green, T. J. Cole, Heaven Crawley, N. Lessof, L. R. Boag, and R. M. M. Wallace, "Medical, Statistical, Ethical and Human Rights Considerations in the Assessment of Age in Children and Young People Subject to Immigration Control," British Medical Bulletin 102 (2012): 2.

50 Office of the United Nations High Commissioner for Refugees Birth Registration.
51 Kevin Sieff. "Happy Birthday to the Afghans Who Don't Know When They Were Born," Independent, 1 January 2014, http://www.independent.co.uk/news/world/asia/happybirthday-to-the-afghans-who-don-t-know-when-theywere-born-9032985.html.

52 aida: Asylum Information Database, "Detriment of the Doubt:AgeAssessmentofUnaccompanied Asylum-Seeking Children," December 2015, 1, http://www.asylumlawdatabase.eu/sites/www.asylumlawdatabase.eu/files/aldfiles/ AIDA\%20Brief\%205_AgeAssessment.pdf.

53 Catherine Gladwell and Hannah Elwyn, "Broken Futures: Young Afghan Asylum-seekers in the UK and on Return to Their Country of Origin," New Issues in Refugee Research Paper No. 246 (Geneva 2012), 24.

54 Court of Appeal, $R$ (on the application of $H N$ and $S A$ ) (Afghanistan) $v$ the Secretary of State for the Home Department.

55 Gladwell, "No Longer a Child," 62-3; Gladwell et al., After Return, 57.

56 Robinson and Williams, "Leaving Care," 86.

57 Rygiel, "Bordering Solidarities."

58 See Kaytaz,"Resigned.”

59 Alex Matthews, “'Child' Asylum-seeker Caught Out by His Teeth: Afghan Who Claimed to Be Just 12 Is Revealed to Be in His TwENTIEs after Assaulting His British Foster Father," Daily Mail, 20 February 2016, http://www.dailymail .co.uk/news/article-3455875/Adult-asylum-seekerclaimed-just-12-assaulted-foster-carer-caught-lookingchild-porn.html.

60 Ibid.

61 Rowena Mason, "Child Refugees Will Have Ages Verified if Necessary, Minister Says," Guardian, 21 October 2016, https://www.theguardian.com/world/2016/oct/21/childrefugees-will-have-ages-verified-if-necessary-ministersays.

62 See, e.g., Judith Dennis, Not a Minor Offence: Unaccompanied Children Locked Up as Part of the Asylum System (London: Refugee Council Briefings, 2012); Emily Dugan, "Exclusive: Children Are Still Held in Adult Detention Centres Despite Coalition Pledges to End the Practice," Independent, 9 January 2014, http://www.independent .co.uk/news/uk/politics/exclusive-children-are-still-heldin-adult-detention-centres-despite-coalition-pledgesto-end-the-practice-9050170.html; Joint Committee on Human Rights, Human Rights of Unaccompanied Migrant Children, 31; Maeve McClenaghan, "Vulnerable Children Locked Up in Immigration Detention Centres for Adults due to Home Office Blunders," Bureau of Investigative Journalism, 22 June 2015, https://www.thebureauinvestigates.com/2015/06/22/asylum-seeking-children-lockedup-adult-immigration-detention-centre-due-to-homeoffice-blunders/.

63 Mark Townsend, "Anger as 'Panicking' Home Office Puts Minors in Detention Centre," Guardian, 23 October 2016, https://www.theguardian.com/world/2016/oct/22/ 
anger-panicking-home-office-houses-refugee-childrendetention-centre-calais.

64 Independent Age Assessment, "Services," 2014, http:// www.independentageassessment.co.uk/services.htm.

65 Aynsley-Green et al., "Medical, Statistical, Ethical and Human Rights Considerations."

66 Patrick Thevissen, S. I. Kvaal, Kris Dierick, and Guy Willems "Ethics in Age Estimation of Unaccompanied Minors," Journal of Forensic Odonto-Stomatology 30 (2012): 85-102.

67 Separated Children in Europe Network, "Position Paper," 7.

68 Aynsley-Green et al., "Medical, Statistical, Ethical and Human Rights Considerations"; Jill Benson, "Age Determination in Refugee Children," Australian Family Physician 37 (2008): 821-4; S. Mora, M. Boechat, E. Peitka, H. Huang, and V. Gilsanz, "Skeletal Age Determinations in Children of European and African Descent: Applicability of the Greulich and Pyle Standards," Pediatric Resident 50 (2001): 624-7.
69 aida: "Detriment of the Doubt," 6; Cole, "People Smugglers." 70 Separated Children in Europe Network, "Position Paper," 8.

71 See, e.g., Richard Hugman, Linda Bartolomei, and Eileen Pittaway, "Human Agency and the Meaning of Informed Consent: Reflections on Research with Refugees," Journal of Refugee Studies 24 (2011): 655-71; Mollie Gerver, "Exceptions to Blanket Anonymity for the Publication of Interviews with Refugees: African Refugees in Israel as a Case Study," Research Ethics 9 (2013): 121-39.

Stephanie J. Silverman is a sSHRC postdoctoral fellow and Bora Laskin National Fellow in Human Rights Research at the Graduate School of Public and International Affairs, University of Ottawa. The author may be contacted at sj.silverman@gmail.com. 